\title{
FOREWING DIFFERENTIATION OF THE HONEY BEES FROM SERBIA
}

\author{
N. Nedić ${ }^{1}$, G. Jevtić ${ }^{2}$, G. Jež ${ }^{1}$, B. Anđelković ${ }^{2}$, S. Milosavljević ${ }^{3}$, M. \\ Kostić $^{4}$
}

${ }^{1}$ University of Belgrade, Faculty of Agriculture, 11000, Belgrade-Zemun, Republic of Serbia

${ }^{2}$ Institute for Forage Crops, 37000, Krusevac, Republic of Serbia

${ }^{3}$ High School of Agriculture and Food Technology, 18400, Prokuplje, Republic of Serbia

${ }^{4}$ Institute for Medicinal Plant Research "Dr Josif Pančić", 11000 Belgrade, Republic of Serbia Corresponding author: nedicn@agrif.bg.ac.rs

Original scientific paper

\begin{abstract}
In this study, 12 morphological characteristics were measured on worker bee samples collected from seven different locations covering the territory of Republic Serbia. The measurement of 11 angles on the front wing and cubital index was done with stereo microscope Leica XTL-3400D, and software package IL 1009 in accordance with the standard method. The results showed significant differences between the groups of bees and investigation of angles on the forewing could be contributed to a clearer separation of groups of bees inside domestic population.
\end{abstract}

Key words: honey bee, morphometry, angle, cubital index

\section{Introduction}

Serbia has excellent prerequisites for the development of beekeeping, distinguished by heterogeneous relief and climatic conditions and by the existence of various honey bee pasture. Considering the area of wild flora, Serbia takes the sixth place in the world with a total of 1.28 million hectares which presents a great nectar potential for honey bee (www.organic-world.net). Due to the adaptable abilities of bees, it is assumed that there was a creation of different geographic ecotypes of bees in Serbia adapted to specific habitat conditions.

According to Ruttner (1992) Carniolan honey bee subspecies (Apis mellifera carnica Poll.) inhabits a large territory and encompasses the present-day Austria, Slovenia, Croatia, Hungary, Bosnia and Herzegovina, Montenegro, Serbia, Romania, Bulgaria, Macedonia and part of northern Greece. For the identification of bee species and subspecies morphometry represents very powerful tool (Francoy et al., 2006). The first attempts to classify bee subspecies were based on color and size (Ruttner et al., 1978). For more complete morphological analysis, DuPraw 
(1965) introduced the measurement of 11 angles on the front wing and noted that these angles as well as other morphometric characters contribute to the classification of samples of different subspecies of honeybees (Stevanović, 2002). These characters are little influenced by environmental conditions and, thus, they represent good indicators of genetic relationships between populations (Meixner et. al., 2007). Morphometric methods represent a powerful investigative tool and have shown high efficacy in controlling the breeding of pure honry bee breed $A . \mathrm{m}$. carnica (Stevanović, 2002; Kauhausen-Keller and Keller, 1994).

The first written record of the varieties of honey bees in Serbia can be found in the work Živanović (1893), and later Grozdanić (1926) suggested the separation of the bees from Banat into subspecies $A$. m. banatica based on morphological comparisons of honey bee samples of from Banat with $A . m$. carnica, A. m. ligustica, A. m. cypria and A. m. syriaca. Our numerous authors studied the morphometric variation in Carniolan honey bee (Vlatković, 1957; Konstantinović, 1965; Krunić, 1967; Plužnikov, 1995; Nedić i sar., 2007; Nedić, 2009; Mladenović i Simeonova, 2010) looking for the ecotypes of indigenous honey bee. However, during the previous decades the natural populations of Carniolan honey bee have been subjected to influence of man, in the first place through the uncontrolled import and crossbreeding to which migratory beekeeping has contributed Today there is the view that two populations of honey bees can be considered in Serbia: gray bees (Apis mellifera carnica Poll.) and yellow bees (Apis mellifera banatica) (Mladenović and Simeonova, 2010).

It is important to identify variation among Serbian honey bee populations, in order to help distinguish and preserve indigenous honey bee breed. Therefore the main aim of this study was to analyze the size of the 11 angles of the front wing and the cubital index value of honey bee samples from different locations of the territory of Serbia.

\section{Materials and Methods}

Samples of 10 adult worker bees (Rinderer, 1993; Arias et al., 2006) were collected from 7 different apiaries along Serbia: Zubin Potok $\left(42^{\circ} 91^{\prime} 82.64^{\prime \prime} \mathrm{N}\right.$, $\left.20^{\circ} 69^{\prime} 43.67^{\prime \prime} \mathrm{E}\right)$, Užice $\left(43^{\circ} 86^{\prime} 62.79^{\prime \prime} \mathrm{N}, 19^{\circ} 82^{\prime} 63.82^{\prime \prime} \mathrm{E}\right)$, Sivac $\left(45^{\circ} 70^{\prime} 45.90^{\prime \prime} \mathrm{N}\right.$, $\left.19^{\circ} 38^{\prime} 53.21^{\prime \prime} \mathrm{E}\right), \quad$ Knjaževac $\left(43^{\circ} 59^{\prime} 73.83^{\prime \prime N} \quad 22^{\circ} 25^{\prime} 63.16^{\prime \prime E}\right), \quad$ Prijepolje $\left(43^{\circ} 38^{\prime} 47.80^{\prime \prime} \mathrm{N}, 19^{\circ} 64^{\prime} 64.09^{\prime \prime} \mathrm{E}\right)$, Kraljevo $\left(43^{\circ} 75^{\prime} 16.78^{\prime \prime} \mathrm{N}, 20^{\circ} 64^{\prime} 36.77^{\prime \prime} \mathrm{E}\right)$, Vršac $\left(45^{\circ} 18^{\prime} 26.59^{\prime \prime} \mathrm{N}, 21^{\circ} 43^{\prime} 41.50^{\prime \prime} \mathrm{E}\right)$. The distant sample locations were chosen to represent different parts of the country with different ecological conditions. Bees were preserved in $95 \%$ ethanol, and then dissected, and the right forewings were mounted on glass slides (Rinderer, 1991) and measured using Leica XTL-3400D binocular microscope and software package IL 1009 in accordance with the standard method by Ruttner et al. (1978). The following characters were used for 
measurements: angle $\mathrm{A} 4$, angle $\mathrm{B} 4$, angle $\mathrm{D} 7$, angle $\mathrm{E} 9$, angle $\mathrm{L} 13$, angle $\mathrm{J} 10$, angle J16, angle N23, angle K19, angle G18, angle O26 and cubital index (CI).

Univariate (variance) statistical analyses were conducted for 12 morphological characteristics of worker bee samples from different locations of the territory of Serbia. A descriptive statistical analysis was carried out and comparisons between locations were determined by Duncan's Studentized Multiple Range Test.

All measurements of morphological characteristics for the bees were analysed by multivariate discriminant analyses. Both statistical analyses (univariate and multivariate) were performed with program package "Statistica 5.0" and results of these analyses were interpreted.

\section{Results and Discussion}

Descriptive statistical values of morphological characteristics of honeybees from different locations in Serbia are summarized in table 1. The results of the measurements of the sampled worker bees showed wide variation of the means and standard deviations for the examined forewing characters. Average value for angle A4 was $29.80^{\circ}$ with range from $28.94^{\circ}$ (Užice) to $30.99^{\circ}$ (Prijepolje), but without statistical significance between sites. The obtained value for this angle is consistent with the results published by Stevanovic (2002) where the value of the angle A4 was $30.1 \pm 1.19^{\circ}$. Average values for angles B4, D7, E9 and K19 were $107.89^{\circ}$, $96.74^{\circ}, 22.94^{\circ}$ and $78.36^{\circ}$, respectively. The values published by Nedić (2009) for the wing characteristics B4 $\left(107,59^{\circ}\right)$, D7 $\left(98.33^{\circ}\right)$, E9 $\left(22.21^{\circ}\right)$ and K19 $\left(78.87^{\circ}\right)$ of the different lines of Apis mellifera carnica Poll. from Serbia closely correspond to the results in our study. The highest values for these angles were measured in a sample of bees from Sivac (Western Bačka region, Vojvodina) and they deviate from the values found in bees from the other sites. Analysis of variance showed that the values of these angles differ significantly between sites $(\mathrm{P}<0.01)$. For L13 angle (14.69), statistically significant differences between sites were not determined. Stevanović (2002) previously studied wing characteristics J10 $\left(49.0^{\circ}\right)$, $\mathrm{J} 16\left(97.2^{\circ}\right)$ and $\mathrm{N} 23\left(92.8^{\circ}\right)$ and these results were different from our present study, except for angle N23. Results of variance analysis testing of these characters show significant differences among locations $(\mathrm{P}<0.01)$. The value of $\mathrm{CI}$ in our study from workers sampled at seven apiaries was 2.64 (table 1) within the range of 2.40 (Prijepolje) to 2,92 (Sivac) and correspond with those from Konstantinović (1965), Ruttner (1988), Georgijev (2006), altough different results for CI were presented by Mladenović and Simeonova (2008).

The values published by Maul and Hahnle (1994) for the reference sample of A. m. carnica for the wing characteristics A4 $\left(29.0^{\circ}\right)$, B4 $\left(112,7^{\circ}\right), \mathrm{D} 7\left(99,3^{\circ}\right)$, E9 $\left(23,3^{\circ}\right), \mathrm{G} 18\left(92,7^{\circ}\right), \mathrm{J} 10\left(52,5^{\circ}\right), \mathrm{J} 16\left(96,4^{\circ}\right), \mathrm{K} 19\left(79,4^{\circ}\right), \mathrm{L} 13\left(12,3^{\circ}\right), \mathrm{N} 23\left(94,4^{\circ}\right)$, 
O26 $\left(37,9^{\circ}\right)$ and CI $(2,6)$ are the most closely correspond to the values for bees from Sivac, and are noticeably different from results for our bee samples from other localities. This can be explained by traditional breeding of queen bee of unknown origin, trading such queen bees, and massive replacement in the colonies. Also, it should be noted that the site Vršac is situated next to the border with Romania and it is likely that in this lowland area there was an interference of bees from different geographic areas. Specifics of bees from the site Zubin Potok lies in the fact that in this region, located in Kosovo, trade and transport of goods is difficult. Due to this fact, this honey bee group remains geographically isolated and possesses certain characteristics which are confirmed in researches of Mladenović and Simeonova (2010).

Table 1. Means and standard deviation (Sd) of selected measures for the bee samples from Serbia. Sizes of angles are given in degree $\left({ }^{\circ}\right)$.

\begin{tabular}{|c|c|c|c|c|c|c|c|c|}
\hline \multirow[b]{2}{*}{ Char. } & \multicolumn{7}{|c|}{ Origin of Samples (locations) } & \multirow[b]{2}{*}{ Average } \\
\hline & Zubin potok & Užice & Sivac & Knjaževac & Prijepolje & Kraljevo & Vršac & \\
\hline A4 & $\begin{array}{c}29,06 \pm 2,21 \\
a^{*}\end{array}$ & $\begin{array}{c}28,94 \pm 1,57 \\
\mathrm{a}\end{array}$ & $\begin{array}{c}29,49 \pm 1,64 \\
\mathrm{a}\end{array}$ & $\begin{array}{c}30,44 \pm 2,07 \\
\mathrm{a}\end{array}$ & $\begin{array}{c}30,49 \pm 1,61 \\
\mathrm{a}\end{array}$ & $\begin{array}{c}30,99 \pm 1,87 \\
\mathrm{a}\end{array}$ & $\begin{array}{c}29,22 \pm 1,45 \\
\mathrm{a}\end{array}$ & $29,80 \pm 1,87$ \\
\hline B4 & $\begin{array}{c}108,84 \pm 6,24 \\
\text { abc }\end{array}$ & $\begin{array}{c}109,87 \pm 3,63 \\
\text { ac }\end{array}$ & $\begin{array}{c}113,17 \pm 3,72 \\
\mathrm{a}\end{array}$ & $\begin{array}{c}106,38 \pm 3,75 \\
\text { bc }\end{array}$ & $\begin{array}{c}106,63 \pm 6,12 \\
\text { bc }\end{array}$ & $\begin{array}{c}103,39 \pm 4,63 \\
\text { b }\end{array}$ & $\begin{array}{c}106,98 \pm 5,81 \\
b c\end{array}$ & $107,89 \pm 5,58$ \\
\hline D7 & $\begin{array}{c}95,29 \pm 3,30 \\
\text { b }\end{array}$ & $\begin{array}{c}98,03 \pm 2,55 \\
a b\end{array}$ & $\begin{array}{c}100,10 \pm 3,62 \\
\mathrm{a} \\
\end{array}$ & $\begin{array}{c}96,74 \pm 2,64 \\
a b\end{array}$ & $\begin{array}{c}97,61 \pm 2,21 \\
a b\end{array}$ & $\begin{array}{c}94,49 \pm 3,84 \\
\text { b }\end{array}$ & $\begin{array}{c}94,93 \pm 2,49 \\
\mathrm{~b}\end{array}$ & $96,74 \pm 3,43$ \\
\hline E9 & $\begin{array}{c}23,13 \pm 1,53 \\
\text { abc }\end{array}$ & $\begin{array}{c}22,48 \pm 1,10 \\
\text { bc }\end{array}$ & $\begin{array}{c}24,28 \pm 1,22 \\
\mathrm{a} \\
\end{array}$ & $\begin{array}{c}22,24 \pm 1,35 \\
\text { bc }\end{array}$ & $\begin{array}{c}23,69 \pm 1,68 \\
a b\end{array}$ & $\begin{array}{c}21,93 \pm 1,13 \\
\mathrm{c}\end{array}$ & $\begin{array}{c}22,84 \pm 1,38 \\
\text { abc }\end{array}$ & $22,94 \pm 1,51$ \\
\hline L13 & \begin{tabular}{|c|}
$14,25 \pm 1,25$ \\
$\mathrm{a}$ \\
\end{tabular} & \begin{tabular}{|c|}
$15,03 \pm 1,17$ \\
$\mathrm{a}$ \\
\end{tabular} & \begin{tabular}{|c|}
$13,82 \pm 1,90$ \\
$\mathrm{a}$ \\
\end{tabular} & \begin{tabular}{|c|}
$14,16 \pm 1,20$ \\
$\mathrm{a}$ \\
\end{tabular} & $\begin{array}{c}14,09 \pm 0,75 \\
\mathrm{a} \\
\end{array}$ & \begin{tabular}{|c|}
$15,38 \pm 0,90$ \\
$\mathrm{a}$ \\
\end{tabular} & \begin{tabular}{|c|}
$14,69 \pm 2,04$ \\
$\mathrm{a}$ \\
\end{tabular} & $14,49 \pm 1,43$ \\
\hline $\mathrm{J} 10$ & $\begin{array}{c}56,09 \pm 3,29 \\
\mathrm{a} \\
\end{array}$ & $\begin{array}{c}51,22 \pm 2,36 \\
\mathrm{~b}\end{array}$ & $\begin{array}{c}52,73 \pm 2,66 \\
a b\end{array}$ & $\begin{array}{c}55,37 \pm 3,74 \\
a b \\
\end{array}$ & $\begin{array}{c}53,61 \pm 4,00 \\
a b\end{array}$ & $\begin{array}{c}53,78 \pm 3,19 \\
a b\end{array}$ & $\begin{array}{c}52,77 \pm 3,88 \\
a b\end{array}$ & $53,67 \pm 3,56$ \\
\hline J16 & $\begin{array}{c}90,01 \pm 2,03 \\
a b \\
\end{array}$ & \begin{tabular}{|c|}
$93,45 \pm 2,96$ \\
$\mathrm{a}$ \\
\end{tabular} & $\begin{array}{c}88,65 \pm 3,58 \\
\mathrm{~b}\end{array}$ & $\begin{array}{c}92,19 \pm 2,81 \\
a b \\
\end{array}$ & $\begin{array}{c}93,10 \pm 3,72 \\
\mathrm{a} \\
\end{array}$ & $\begin{array}{c}89,95 \pm 4,70 \\
a b\end{array}$ & $\begin{array}{c}92,72 \pm 2,10 \\
\mathrm{a} \\
\end{array}$ & $91,44 \pm 3,56$ \\
\hline N23 & \begin{tabular}{|c|}
$94,87 \pm 3,19$ \\
$\mathrm{a}$ \\
\end{tabular} & \begin{tabular}{|c|}
$93,61 \pm 2,63$ \\
$a b c$
\end{tabular} & \begin{tabular}{|c|}
$90,26 \pm 2,40$ \\
$\mathrm{~cd}$
\end{tabular} & \begin{tabular}{|c|}
$94,16 \pm 3,07$ \\
$a b$
\end{tabular} & $\begin{array}{c}95,00 \pm 3,03 \\
\mathrm{a} \\
\end{array}$ & $\begin{array}{c}89,04 \pm 3,87 \\
\mathrm{~d}\end{array}$ & $\begin{array}{c}91,03 \pm 2,23 \\
\text { bcd }\end{array}$ & $92,57 \pm 3,62$ \\
\hline K19 & $\begin{array}{c}77,01 \pm 1,44 \\
a b\end{array}$ & $\begin{array}{c}78,18 \pm 2,18 \\
a b\end{array}$ & $\begin{array}{c}79,61 \pm 2,61 \\
\mathrm{~b}\end{array}$ & $\begin{array}{c}76,69 \pm 3,47 \\
b\end{array}$ & $\begin{array}{c}79,40 \pm 1,94 \\
a b\end{array}$ & $\begin{array}{c}78,44 \pm 1,83 \\
a b\end{array}$ & $\begin{array}{c}79,19 \pm 2,07 \\
a b\end{array}$ & $78,36 \pm 2,45$ \\
\hline G18 & $\begin{array}{c}91,50 \pm 2,06 \\
\mathrm{a} \\
\end{array}$ & $\begin{array}{c}91,26 \pm 3,94 \\
\mathrm{a} \\
\end{array}$ & $\begin{array}{c}90,13 \pm 4,21 \\
\mathrm{a} \\
\end{array}$ & $\begin{array}{c}89,75 \pm 0,96 \\
\mathrm{a} \\
\end{array}$ & $\begin{array}{c}92,98 \pm 2,86 \\
\mathrm{a} \\
\end{array}$ & $\begin{array}{c}90,03 \pm 1,88 \\
\mathrm{a} \\
\end{array}$ & $\underset{\mathrm{a}}{89,16 \pm 3,51}$ & $90,69 \pm 3,10$ \\
\hline $\mathrm{O} 26$ & $\begin{array}{c}36,49 \pm 4,53 \\
\text { a }\end{array}$ & $\begin{array}{c}35,47 \pm 3,28 \\
\text { a }\end{array}$ & $\begin{array}{c}34,88 \pm 3,49 \\
\text { a }\end{array}$ & $\begin{array}{c}38,27 \pm 2,67 \\
\text { a }\end{array}$ & $\underset{\text { a }}{35,99 \pm 2,60}$ & $\begin{array}{c}37,44 \pm 2,68 \\
\text { a }\end{array}$ & $\begin{array}{c}34,94 \pm 3,12 \\
\text { a }\end{array}$ & $36,21 \pm 3,34$ \\
\hline CI & $\underset{\mathrm{a}}{2,45 \pm 0,42}$ & $\underset{\mathrm{a}}{2,63 \pm 0,39}$ & $\underset{\mathrm{a}}{2,92 \pm 0,64}$ & $\underset{\mathrm{a}}{2,61 \pm 0,52}$ & $\underset{\mathrm{a}}{2,40 \pm 0,40}$ & $\underset{\mathrm{a}}{2,83 \pm 0,25}$ & $\underset{\mathrm{a}}{2,65 \pm 0,42}$ & $\underset{\mathrm{a}}{2,64 \pm 0,46}$ \\
\hline
\end{tabular}

*Means for the same characteristics followed by different letters within locations are significantly different $(\mathrm{P}<0.01)$ according to variance analysis followed by Duncan's Studentized multiple range tests. 
For the characterization of subpopulations within races, multivariate statistical methods may be used to estimate similarities and/or dissimilarities (Kauhausen-Keller and Keller, 1994).

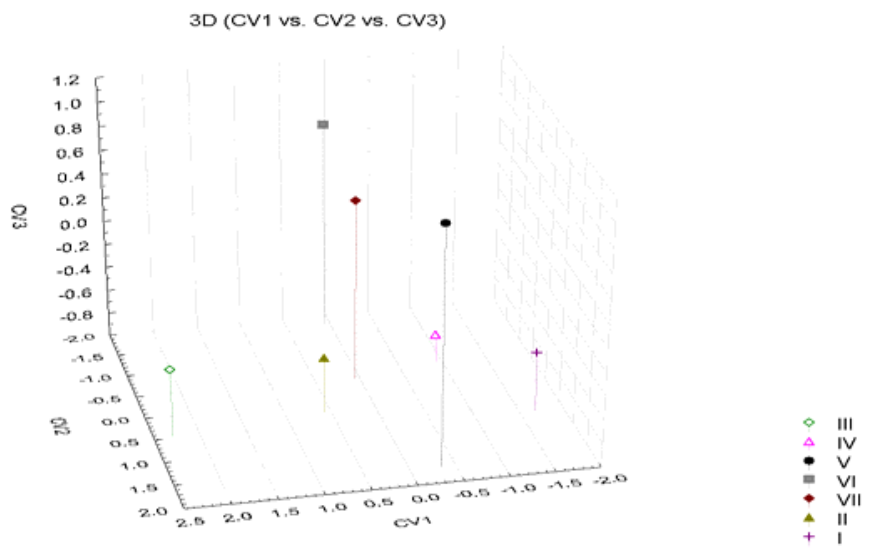

Figure 1. Three-dimensional view of the distribution of bee groups centroids by location

The results of multivariate discriminant analyses of the measurements of the 12 characteristics showed significant differences existed between the seven groups of bees (Wilk's $\lambda=0.0591, \mathrm{P}<0.00001)$. The $1^{\text {st }}$ axis (CV 1) explained $37.2 \%$, the $2^{\text {nd }}(\mathrm{CV} 2) 29.1 \%$ and the $3^{\text {rd }}$ axis (CV 3) $12.3 \%$ of the total variation. Thus $78.6 \%$ of the total variation could be explained by first three canonical variants. According to these analyses the local honey bee samples from Sivac in West Bačka region (group III) showed most difference compared to most other groups of bees (Figure 1). This separation of characters was most contributed by angle J10, angle B4, angle D7 and CI. Results of the analysis of morphological characters indicate the existence of distinct local subpopulations, and this is clearly illustrated by the bees from the area Sivac and Zubin Potok. Evidently, the habits of introduction of queens of unknown origin, migratory beekeeping and overlapping with nearest foreign subspecies in the border region cause the mixing of bees in different regions in Serbia.

\section{Conclusion}

Based on the research, the existence of significant variability between the groups of bees in Serbia was determined. Results of variance analysis testing showed differences among locations in regards to 7 morphometric characters. Angles: B4, D7, E9, J10, J16, N23 and K19 were found to show significant differences among locations $(\mathrm{P}<0.01)$, while the differences between other characters were not significant considering locations. 
Multivariate discriminant analysis showed that significant differences existed among the sampled groups of honey bees (Wilk's $\lambda=0.0591, \mathrm{P}<0.00001$ ), where the group of honey bees from site Sivac was clearly distinguished.

The values of certain morphometric characters of examined groups of bees from different geographic localities showed a deviation from the standard values for Carniolan honey bee race. These results suggest that the human activities like introduction of other honey bee subspecies into different geographic areas produced admixtures of native subspecies (A. m. carnica Poll.) in Serbia.

Analysis of the front wing characters has effectively contributed to the discrimination of bees sampled. So in the future this type of research should be included in the honey bee breeding program in order to separate carnica and the hybrid population of honeybees in Serbia.

\title{
Acknowledgment
}

Research was financed by the Ministry of Education and Science, Republic of Serbia, projects 46008 and 46009 . We are grateful to all beekeepers that contributed to worker bee samples.

\section{Diferencijacija prednjeg krila medonosne pčele iz Srbije}

\author{
N. Nedić, G. Jevtić, G. Jež, B. Anđelković, S. Milosavljević, M. Kostić
}

\section{Rezime}

U ovom istraživanju mereno je 12 morfoloških karakteristika prednjeg krila pčela radilica u skladu sa metodama Ruttner $i$ sar. (1978). Uzorci pčela radilica su prikupljeni sa 7 različitih lokacija čime su pokriveni glavni pčelarski regioni na teritoriji Republike Srbije. Morfometrijska istraživanja pokazala su da pčele iz Zapadno Bačkog regiona u Vojvodini imaju najveću vrednost uglova B4 $\left(113,17^{\circ}\right)$, D7 $\left(100,10^{\circ}\right)$, E9 $\left(24,28^{\circ}\right)$, K19 $\left(79,60^{\circ}\right)$ i najveći kubitalni indeks $(2,92)$. Iste pčele se na osnovu multivarijantne diskriminantne analize najviše razlikuju od grupe pčela sa Kosova. Na osnovu analize varijanse, utvrđeno je da postoji vrlo značajna razlika $(\mathrm{P}<0.01)$ u 7 morfoloških karakteristika između grupa pčela sa izabranih lokaliteta. Može se zaključiti da utvrđene vrednosti za ispitivane karaktere ukazuju na postojanje značajne varijabilnosti i impliciraju na postojanje subpopulacija uslovljenih delovanjem čoveka. 


\section{References}

ARIAS C.M., RINDERER E.T., SHEPPARD S.W. (2006): Further characterization of honey bees from the Iberian Peninsula by allozyme, morphometric and mtDNA haplotype analyses. Journal of Apicultural Research, 45, 4, 188-196.

DUPRAW E.J. (1964): Non-Linnean. Nature, 202, 849-852.

GEORGIJEV (2006): Biološko-produktivne osobine medonosne pčele u istočnoj Srbiji. Magistarski rad, Poljoprivredni fakultet Beograd, 1-149.

GROZDANIĆ S. (1926): “Žuta” banatska pčela. Glasnik entomološkog društva, 1, 1-16.

FRANCOY T.M., PRADO R.R.P., GONCALVES S.L., COSTA F.L., DE JONG D. (2006): Morphometric differences in a single wing cell can discriminate Apis mellifera racial types. Apidologie, 37, 91-97.

KAUHAUSEN-KELLER D., KELLER R. (1994): Morphometrical control of pure race breeding in the honeybee (Apis mellifera L.). Apidologie, 25, 133-143.

KONSTANTINOVIĆ B. (1965): Uticaj priprema društva medonosne pčele (Apis mellifica L.) na iskorišćavanje pčelinje paše sliva Zapadne Morave. Doktorska disertacija, Poljoprivredni fakultet, Beograd, 1-144.

KRUNIĆ M. (1967): Varijabilitet Apis mellifica L. u Jugoslaviji sa posebnim osvrtom na diferencijaciju populacija u panonskoj niziji. Doktorska disertacija. Biološki fakultet Beograd, 1-64.

MAUL V., HAHNLE A. (1994): Morphometric studies with pure bred stock of Apis mellifera carnica Pollmann from Hessen. Apidiologie, 25, 119-132.

MEIXNER M., WOROBIK M., WILDE J., FUCHS S., KOENIGER N. (2007): Apis mellifera mellifera in eastern Europe - morphometric variation and determination of its range limits. Apidologie 38, 191-197.

MLADENOVIĆ M., SIMEONOVA V. (2008): Variranje morfometrijskih osobina domaće karnike u repro stanicama na jugu Srbije. Zbornik plenarnih i naučnih radova, XVI Naučno savetovanje sa međunarodnim učešćem «Kvalitetom i selekcijom u pčelarstvu ka Evropi», 9-10. februar, Poljoprivredni fakultet Beograd, $1-6$.

MLADENOVIĆ M., SIMEONOVA V. (2010): The variability of wing nervature angles of honey bee from north Kosovo area. Second Balkan Conference on Biology, 21-23 May 2010., Plovdiv, Bulgaria, Biotechnology \& Biotechnological Equipment 24, 2, 427-432.

NEDIĆ N., MLADENOVIĆ M., STANISAVLJEVIĆ LJ. (2007): Biological and production characteristics of certain lines of honey bee in Serbia. 2nd International Congress on Animal Husbandry: New Perspectives and Challenges of Sustainable Livestock Farming, 3-5 October, Belgrade. Biotechnology in Animal Husbandry, 23, 5-6, 389-398. 
NEDIĆ N. (2009): Biloško-proizvodne osobine medonosne pčele Apis mellifera carnica Poll. na teritoriji Srbije. Doktorska disertacija, Univerzitet u Beogradu, Poljoprivredni fakultet, 1-159.

RINDERER T. E., BUCO S. M., SYLVESTER H. A., STELZER J. A. (1991): Manual for the laboratory preparation of honey bee samples and their analysis with the Universal System for the Detection of Africanized Bees. USDA, ARS, Baton Rouge, Louisiana, USA.

RINDERER T. E., BUCO S., RUBINK W., DALY H., STELZER J., RIGGIO R., BAPTISTA F. (1993): Morphometric Identification of Africanized and European Honey Bees Using Large Reference Populations. Apidologie, 24, 6, 569-585.

RUTTNER F. (1988): Biometrical-statistical analysis of the geographic variability of apis mellifera L. Apidologie, 9, 363-381.

RUTTNER F. (1992): Naturgeschichte der Honigbienen. Ehrenwirth Verlag. Munich. Deutschland, $355 \mathrm{p}$.

RUTTNER F., TASSENCOURT L., LOUVEAUX J. (1978): Biometrical statistical analysis of the geographic variability of Apis mellifera L. I: Materials and methods, Apidologie, 9, 363-382.

STEVANOVIĆ J. (2002): Istraživanja morfometrijske i hromozomske varijabilnosti u funkciji očuvanja diverziteta kranjske medonosne pčele (Apis mellifera carnica Pollman, 1879) na teritoriji Srbije. Magistarska teza. Biološki fakultet, Beograd, 1-190.

VLATKOVIĆ B. (1957): Pčele Sjeničke kotline i visoravni Peštera i uslovi pčelarenja. Acta Veterinaria, 7, 3 - 18.

ŽIVANOVIĆ J. (1983): Srpski pčelar. Knjižara Luke Jocića. Novi Sad, 298.

www.organic-world.net 